\title{
A bi-specific inhibitor A bi-specific inhibitor targeting IL-17A and MMP-9 reduces invasion and motility in MDA-MB-231 cells
}

\author{
Dana Koslawsky¹, Marianna Zaretsky², Ron Alcalay³, Ohad Mazor ${ }^{4}$, Amir Aharoni² \\ and Niv Papo ${ }^{1}$ \\ ${ }^{1}$ Department of Biotechnology Engineering, The National Institute of Biotechnology in the Negev, Ben-Gurion University of \\ the Negev, Beer-Sheva, Israel \\ ${ }^{2}$ Department of Life Sciences, The National Institute of Biotechnology in the Negev, Ben-Gurion University of the Negev, \\ Beer-Sheva, Israel \\ ${ }^{3}$ Department of Biochemistry and Molecular Genetics, Israel Institute for Biological Research, Ness-Ziona, Israel \\ ${ }^{4}$ Department of Infectious Diseases, Israel Institute for Biological Research, Ness-Ziona, Israel \\ Correspondence to: Niv Papo, email: papo@bgu.ac.il
}

Keywords: cancer therapy; cytokines; matrix metalloproteinases; metastasis; drug design

Received: March 27, $2018 \quad$ Accepted: May 14, $2018 \quad$ Published: June 19, 2018

Copyright: Koslawsky et al. This is an open-access article distributed under the terms of the Creative Commons Attribution License 3.0 (CC BY 3.0), which permits unrestricted use, distribution, and reproduction in any medium, provided the original author and source are credited.

\section{ABSTRACT}

The cytokine IL-17A is associated with the progression of various cancers, but little is known about the molecular cross-talk between IL-17A and other tumor-promoting factors. Previous studies have shown that the IL-17A-mediated invasion of breast cancer cells can be inhibited by selective antagonists of the matrix metalloproteinase 9 (MMP-9), suggesting that the cross-talk between IL-17A and MMP-9 may promote cancer invasiveness and metastasis. Here, we present a novel strategy for developing cancer therapeutics, based on the simultaneous binding and inhibition of both IL-17A and MMP-9. To this end, we use a bi-specific heterodimeric fusion protein, comprising a natural inhibitor of MMPs (N-TIMP2) fused with an engineered extracellular domain (V3) of the IL-17A receptor. We show that, as compared with the mono-specific inhibitors of IL-17A (V3) and MMP-9 (N-TIMP2), the engineered bi-specific fusion protein inhibits both MMP-9 activation and IL-17A-induced cytokine secretion from fibroblasts and exhibits a synergistic inhibition of both the migration and invasion of breast cancer cells. Our findings demonstrate, for the first time, that dual targeting of inflammatory (IL-17A) and extracellular matrix remodeling (MMP) pathways can potentially be used as a novel therapeutic approach against cancer. Moreover, the platform developed here for generating the bi-specific IL-17A/MMP-9 inhibitor can be utilized for generating bi-specific inhibitors for other cytokines and MMPs.

\section{INTRODUCTION}

Patients with cancer often exhibit poor response to monospecific therapy [1], in large part due to the multifactorial nature of the disease [2]. It has been suggested that dual-targeting agents, i.e., molecules that can target and manipulate the activity of multiple targets simultaneously, are superior over monospecific agents for clinical applications because they offer improved binding affinity, avidity, potency, and selectivity [3] Most attempts to develop such dual-targeting agents have focused on developing bi-specific antibodies, which can simultaneously bind two antigens - usually well-established targets for cancer therapy - to induce a beneficial synergistic effect [4-8]. However, bi-specific antibodies are difficult to assemble due to their natural dimerization, and they can activate the immune system to induce various side effects [2, 9-12].

Two families of protein that were shown to be important in promoting a variety of different cancers are matrix metalloproteinases (MMPs) and pro-inflammatory cytokines [13]. Of the MMPs, MMP-9 appears to be 
a particularly important target for cancer therapy, as it is involved in extracellular-matrix remodeling, plays a direct role in the expansion of tumor cells [14], promotes tumor metastasis [15], and its increased expression has been associated with various types of cancer [16-22] and cancer-related phenomena $[23,24]$. Of the proinflammatory cytokines, IL-17A has recently been associated with the progression of various types of tumor [25-32] and is considered to be an important target for cancer therapy because its inhibition reduces cancer progression in animal models [33, 34]. For instance, inhibiting IL-17A at tumor sites significantly suppresses CD31, MMP9, and VEGF expression in the tumor [35], while activating its receptor (IL-17RA) promotes early tumor development $[28,36]$. Several studies demonstrated a cross-talk between IL-17A and MMP-9, making these two proteins ideal for dual-inhibition, non-antibody cancer therapy. It was previously shown that IL-17A is associated with an increased expression of MMP-9, leading to enhanced cancer invasiveness and metastasis [31, 32, 37]. In addition, IL-17A stimulates the expression of the MMP-9 mRNA [38], and IL-17A-dependent invasion of breast cancer cells can be inhibited by MMP-9 inhibitors [32]. Furthermore, IL-17A was shown to promote the migration and invasion of cancer cells by up-regulating the expression of MMP-9 and down-regulating the expression of the tissue inhibitor of metalloproteinase 2 (TIMP2) - a natural inhibitor of MMPs — via the p38/NF-kB signaling pathway [36, 39]. Finally, chemotherapy (for example, FOLFOX) is known to increase the expression of IL-17A [40], and an IL-17A neutralizing antibody has been shown to enhance the therapeutic responsiveness of established colon tumors $[40,41]$, which are associated with high MMP-9 activity [42]. Similarly, in breast cancer, higher expression of IL-17 was linked with a greater probability for recurrence, greater chemotherapy resistance (to docetaxel), shorter disease-free survival rate, and a poorer prognosis [34]. These data suggest that chemotherapy induces the remodeling of the tumor microenvironment to support the tumor cellular hierarchy through secreted factors [40]. Since several chemotherapies have been shown to increase the expression of IL-17A, it would be beneficial to combine chemotherapies with IL-17Aneutralizing antibodies.

Such evidence for a cross-talk between IL-17A and MMP-9 suggest that their simultaneously targeting can be highly beneficial for inhibiting tumor progression in various types of cancer, including breast cancer, gastric cancer, cervical cancer, hepatocellular carcinoma, and lung cancer [13, 29, 32, 36, 39].

We recently developed an improved soluble IL17RA, which can efficiently block IL-17A-induced cytokine secretion in a cell line and inhibits psoriasis plaque formation in a mouse model [43]. In addition, we developed a TIMP2 ligand, which targets MMP-9 and shows a potent inhibitory activity in vitro [44]. In the current study, we fused TIMP2 and the engineered soluble IL-17RA to develop a novel bi-specific inhibitor, which simultaneously targets both MMP-9 and IL-17A. We explored the biochemical properties of the mono- and bispecific inhibitors and show that fusing the two individual inhibitors does not compromise their biochemical properties. Using cell-based assays, we found that the bispecific inhibitor exhibits superior inhibition of cancer cell invasion and migration, as compared with the monospecific inhibitors, either alone or together. Our approach for simultaneously targeting MMP-9 and IL-17A paves the way toward the development of bi-specific inhibitors targeting the MMPs and pro-inflammatory cytokines for the generation of novel cancer therapy agents [36, 39].

\section{RESULTS}

\section{Construction and production of the bi-specific MMP-9/IL-17 inhibitor}

We designed the construct of the bi-specific heterodimer, termed here $\mathrm{HD}_{\mathrm{N}-\mathrm{TIMP} 2 \mathrm{~V} 3}$, to contain two main components. The first component is N-TIMP2 - a discrete protein domain that folds independently of the C-terminal domain of TIMP2 [45] and is both necessary and sufficient for inhibiting the catalytic activity of all MMPs [46]. The second component is a soluble IL17RA, termed V3, which contains the extracellular domain of the IL-17A receptor with five point mutations (Supplementary Figure 1) that increase its affinity towards IL-17A by 6-fold [43]. We conjugated the two components by using a peptide linker (Supplementary Figure 2), and then sub-cloned the bi-specific heterodimer into a mammalian vector, which contained the TIMP2 natural leader peptide at the N-terminus, fused with the human IgG1 Fc and a $6 \times$ His sequence at the $\mathrm{C}$ - terminus. Thus, the heterodimer comprised a free N-terminal, which is crucial for its activity because the N-domain of TIMP2 is responsible for the binding and inhibition of MMPs. Both $\mathrm{HD}_{\mathrm{N}-\mathrm{TIMP} 2 \mathrm{~V} 3}$ and V3 were produced in mammalian HEK293F cells, and N-TIMP2 was produced in Pichia pastoris. All proteins were purified by affinity column chromatography and gel filtration as soluble proteins (Supplementary Figure 3A), yielding highly pure $(95 \%-98 \%)$ N-TIMP2, V3, and $\mathrm{HD}_{\mathrm{N}-\mathrm{TIMP} 2 \mathrm{~V} 3}$ (Supplementary Figure 3B). It was previously shown that the extracellular domain of many receptors is highly glycosylated, and that such glycosylation can significantly contribute to the conformation of the receptor and its binding to the target ligand [47]. Indeed, using SDS-PAGE, we found that the mobility of both the bi-specific heterodimer $\mathrm{HD}_{\mathrm{N}-\mathrm{TIMP} 2, \mathrm{~V} 3}$ and $\mathrm{V} 3$ reflects proteins with a much higher molecular weight than predicted based on the amino acid sequence, namely, $\sim 120 \mathrm{kDa}$ instead of $76 \mathrm{kDa}$ for $\mathrm{HD}_{\mathrm{N}-\mathrm{TIMP} 2, \mathrm{~V} 3}$ and $\sim 100 \mathrm{kDa}$ instead of $60 \mathrm{kDa}$ for V3 (Supplementary 
Figure 3C). The reduced mobility is probably due to multiple glycosylations, which, for N-TIMP2, do not affect its binding to MMPs [48, 49]. Glycosylation in V3 was shown previously [43], and, therefore, it was not surprising that $\mathrm{HD}_{\mathrm{N}-\mathrm{TIMP} 2 \mathrm{~V} 3}$ showed differences in the calculated versus the experimentally obtained molecular weight. Differences were also observed in the mass spectrometry analysis of the two proteins (Supplementary Figure 4): while the molecular weight of N-TIMP2 was the same as predicted based on the amino acid sequence, those of $\mathrm{HD}_{\mathrm{N}-\mathrm{TIMP} 2 \mathrm{~V} 3}$ and V3 were higher (namely, 93 $\mathrm{kDa}$ and $76 \mathrm{kDa}$, respectively) than the prediction. As expected, subtracting the molecular weight of V3 from that of $\mathrm{HD}_{\mathrm{N}-\mathrm{TIMP} 2, \mathrm{~V} 3}$, as determined by mass spectrometry, is the molecular weight of N-TIMP2.

\section{HD $_{\text {N-TIMP2,V3 }}$ binds simultaneously to both IL-17A and soluble MMP-9 $_{\text {CAT }}$}

After constructing the $\mathrm{HD}_{\mathrm{N}-\mathrm{TIMP} 2 \mathrm{~V} 3}$ heterodimer, we determined its ability to bind IL-17A and the soluble MMP-9 ${ }_{\mathrm{CAT}}$ (MMP-9 catalytic domain), using the Octet Red biolayer interferometry system [50], such that $\mathrm{HD}_{\text {N-TIMP2,v3 }}$ was immobilized on a Protein-A Octet sensor, while its IL-17A binding sensogram was monitored at different concentrations of IL-17A. Then, the sensograms were fitted with a 1:1 binding model (Figure 1A) and the affinity constant $\left(K_{D}\right)$ was determined. This analysis revealed that the $\mathrm{HD}_{\mathrm{N}-\mathrm{TIMP} 2, \mathrm{~V} 3}$ heterodimer fully retains its ability to bind IL-17A, as its affinity $\left(\mathrm{K}_{\mathrm{D}}\right)$ toward IL-17A was $0.048 \pm 0.006 \mathrm{nM}$ (for comparison, the affinity of V3 toward IL-17A in the same system was $0.122 \pm 0.004 \mathrm{nM}$ ). Similarly, $\mathrm{HD}_{\text {N-TIMP2,V3 }}$ retained its ability to bind MMP-9 ${ }_{\mathrm{CAT}}$ (Figure 1B), with a $K_{D}$ of $1.65 \pm 0.02 \mathrm{nM}$.

To characterize the ability of $\mathrm{HD}_{\mathrm{N}-\mathrm{TIMP} 2 \mathrm{~V} 3}$ to simultaneously bind both IL-17A and soluble MMP$9_{\mathrm{CAT}}$, the heterodimer was immobilized on a Protein-A Octet sensor and submerged in a well containing IL17A, which resulted in a wavelength shift (Figure 1C). Following a short wash, the $\mathrm{HD}_{\mathrm{N}-\mathrm{TIMP} 2, \mathrm{~V} 3}-\mathrm{IL}-17 \mathrm{~A}$ complex was immersed in a solution containing MMP$9_{\mathrm{CAT}}$, which resulted in an additional shift, indicating that the heterodimer indeed binds these two ligands simultaneously. As a control, we immobilized the mono-specific V3 on a Protein-A Octet sensor and examined its interaction with IL-17A, which resulted in a wavelength shift (Figure 1D). In contrast to the heterodimer, submerging the V3-IL-17A complex in a solution containing MMP-9 ${ }_{\mathrm{CAT}}$ did not result in a wavelength shift (Figure 1D), indicating that the IL-17 and MMP-9 ${ }_{\mathrm{CAT}}$ ligands did not bind to each other. Taken together, these experiments demonstrate that the $\mathrm{HD}_{\mathrm{N}}$ TIMP2,V3 heterodimer simultaneously binds both its ligands with high affinity.

\section{$\mathrm{HD}_{\mathrm{N}-\mathrm{TIMP} 2, \mathrm{~V} 3}$ inhibits the activity of MMP-9 ${ }_{\mathrm{CAT}}$ and IL-17A in vitro}

To test whether the purified $\mathrm{HD}_{\mathrm{N}-\mathrm{TIMP} 2 \mathrm{~V} 3}$ inhibits the activity of MMP-9 ${ }_{\text {CAT }}$ in vitro, we employed an enzymatic activity assay. This assay indicated that $\mathrm{HD}_{\mathrm{N}-\mathrm{TIMP} 2, \mathrm{~V} 3}$ inhibits the catalytic activity of MMP-9 ${ }_{\mathrm{CAT}}$ (Figure $2 \mathrm{~A}$ ) with a $K_{i}$ of $99 \pm 11 \mathrm{pM}$, which is similar to that previously reported for the inhibition of MMP- ${ }_{\text {CAT }}$ by N-TIMP2 $\left[K_{i}\right.$ of $100 \pm 8 \mathrm{pM}$ [44]] and is in agreement with the $K_{D}$ value of the binding of $\mathrm{HD}_{\mathrm{N}-\mathrm{TIMP} 2, \mathrm{~V} 3}$ to MMP-9 ${ }_{\mathrm{CAT}}(1.65 \pm 0.03$ $\mathrm{nM})$. As expected, V3 alone did not inhibit the activity of MMP-9 ${ }_{\text {CAT }}$ even at a concentration of $50 \mathrm{nM}$.

To test whether the purified $\mathrm{HD}_{\mathrm{N}-\mathrm{TIMP} 2 \mathrm{~V} 3}$ can bind IL$17 \mathrm{~A}$ in vitro, we used an ELISA assay, which indicated that the binding to IL-17A is similar in both $\mathrm{HD}_{\mathrm{N}-\mathrm{TIMP} 2 \mathrm{~V} 3}$ and V3 (Figure 2B). Next, to examine the ability of $\mathrm{HD}_{\mathrm{N}-\mathrm{TIMP} 2, \mathrm{~V} 3}$ to inhibit the binding of IL-17A to IL-17RA in cells, we measured the inhibition of IL-17A-induced cytokine secretion in a cellbased assay, by measuring the secretion of Gro- $\alpha$ following the addition of IL-17A to human fibroblasts [51]. The addition of IL-17A (at $10 \mathrm{ng} / \mathrm{ml}, 0.32 \mu \mathrm{M}$ ) to the fibroblasts resulted in the secretion of more than $120 \mathrm{pg} / \mathrm{ml}$ Gro- $\alpha$ (Supplementary Figure 5). The addition of increasing concentrations of $\mathrm{HD}_{\mathrm{N}}$ TIMP2,V3 together with $0.32 \mathrm{nM} \mathrm{IL-17A}$ to the fibroblasts led to a concentration-dependent inhibition of IL-17A-induced Gro- $\alpha$ secretion (Figure 2C), while the addition of $0.5 \mathrm{mg} /$ $\mathrm{ml}(6.6 \mu \mathrm{M}) \mathrm{HD}_{\mathrm{N}-\mathrm{TIMP} 2, \mathrm{~V} 3}$ completely inhibited the IL-17Ainduced Gro- $\alpha$ secretion (49.2\% secretion, as compared with cells treated only with IL-17A; Figure 2C). $\mathrm{HD}_{\mathrm{N}-\mathrm{TIMP} 2, \mathrm{~V} 3}$ showed similar results to $\mathrm{V} 3$ (the positive control), namely, a $49.2 \%$ secretion as compared with $50 \%$, respectively (Figure 2C), whereas N-TIMP2 (the negative control) did not inhibit Gro- $\alpha$ secretion (Figure $2 \mathrm{C}$ ), as expected. Taken together, these experiments demonstrate that $\mathrm{HD}_{\mathrm{N}-\mathrm{TIMP} 2, \mathrm{~V} 3}$ efficiently inhibits the binding of IL-17A to its endogenous receptor, IL-17RA and inhibits MMP-9 ${ }_{\mathrm{CAT}}$ activity.

\section{HD $_{\text {N-TIMP2,V3 }}$, but not the mono-specific controls, strongly inhibits cancer cell invasion in vitro}

Previously described Matrigel invasion assays showed that the expression and catalytic activity of MMP9 are essential for the invasiveness of different types of cancer cells [52-54], in particular MDA-MB-231 cells $[52,55]$. Additionally, IL-17A was shown to promote the invasion of cancers cells, such as breast [56] and gastric $[36,38]$ cancer cells. As MDA-MB-231 cells express IL-17RA (Supplementary Figure 6), we evaluated the ability of $\mathrm{HD}_{\mathrm{N}-\mathrm{TIMP} 2 \mathrm{~V} 3}$, relative to that of the mono-specific controls, to inhibit the invasion of MDA-MB-231 cells in a Boyden chamber Matrigel invasion assay (Figure 3). MDA-MB-231 cells treated with IL-17A and $500 \mathrm{nM}$ $\mathrm{HD}_{\mathrm{N}-\mathrm{TIMP2} \text {, } 3}$ showed a significantly lower invasiveness than untreated cells or cells treated with IL-17A (45\% 
invasion, as compared with cells treated only with IL-17A; Figure 3A-3C, 3G), either alone or with N-TIMP2, V3 (69\% and $93 \%$ invasion, as compared with cells treated only with IL-17A, respectively; Figure 3D, 3E, 3G), or a combination of N-TIMP2 and V3 (73\% invasion, as compared with cells treated only with IL-17A; Figure $3 \mathrm{~F}$ and $3 \mathrm{G})$. These findings demonstrate the superior inhibitory effect of $\mathrm{HD}_{\mathrm{N}-\mathrm{TIMP} 2, \mathrm{~V} 3}$ over the mono-specific inhibitors (individually or combined), highlighting the importance of the cross-talk between MMP-9 and IL-17A for cell invasion.

\section{$\mathrm{HD}_{\mathrm{N}-\mathrm{TIMP} 2, \mathrm{~V} 3}$ inhibits cell migration in a scratch assay}

To further examine the ability of $\mathrm{HD}_{\mathrm{N}-\mathrm{TIMP} 2 \mathrm{~V} 3}$ (as compared with that of the mono-specific controls) to inhibit
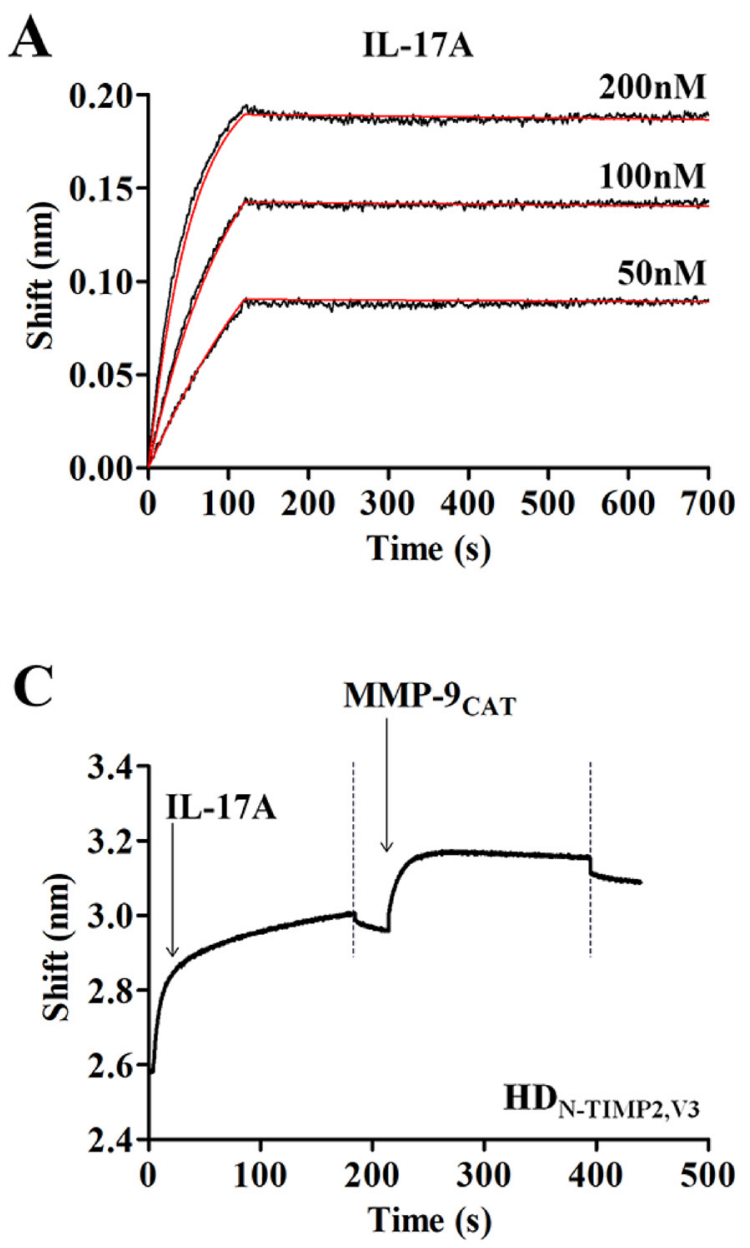

migration of MDA-MB-231 cells, we used a scratch assay. The extension of cell migration was quantified by estimating the percentage of recolonization of the scratch surface, $24 \mathrm{~h}$ after cell wounding (Figure 4). Treating the cells with $0.95 \mu \mathrm{M}$ of IL-17A significantly promoted their migration, as compared with untreated cells (85\% migration, as compared with $100 \%$ migration; Figure $4 \mathrm{~A}, 4 \mathrm{~B}$ and $4 \mathrm{G}$ ). The addition

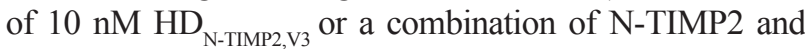
V3 (each at $10 \mathrm{nM}$ ) to IL-17A-treated cells considerably inhibited this migration (42\% migration and 34\% migration, respectively, with no significant difference between the two treatments; Figure 4C, 4F, 4G), whereas the addition of N-TIMP2 or V3 (each at $10 \mathrm{nM}$ ) alone had a smaller effect (65\% and $72 \%$ migration, respectively; Figure 4D, 4E and $4 \mathrm{G})$. Moreover, the inhibition of cell migration by $\mathrm{HD}_{\mathrm{N}}$ TIMP2,V3 was dose-dependent (Supplementary Figure 7).
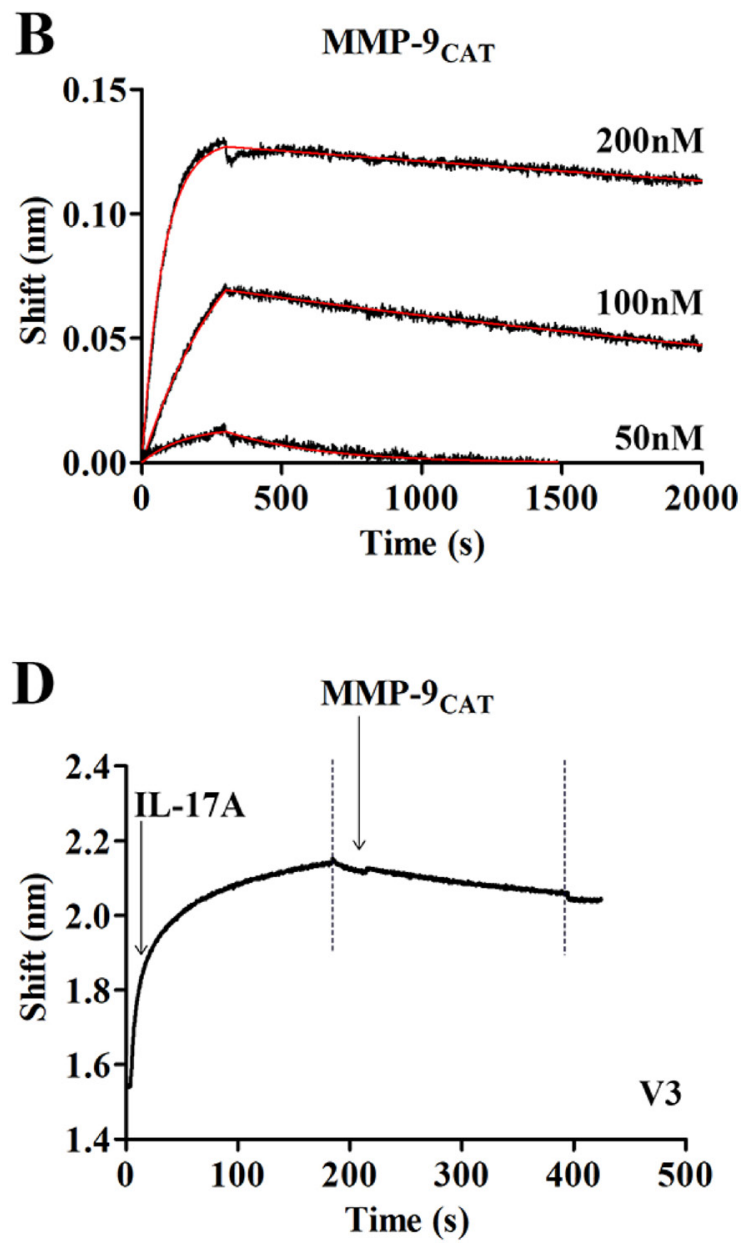

Figure 1: Binding of $\mathbf{H D}_{\mathrm{N}-\mathrm{TIMP2}, \mathrm{V} 3}$ to its ligands, IL-17A and MMP-9 ${ }_{\mathrm{CAT}}$. Real-time binding of $\mathrm{HD}_{\mathrm{N}-\mathrm{TIMP} 2 \mathrm{~V} 3}$ to its ligands was measured by using an Octet Red biolayer interferometry system. $(\mathbf{A}, \mathbf{B}) \mathrm{HD}_{\mathrm{N}-\mathrm{TIMP} 2 \mathrm{~V} 3}$ was immobilized on a Protein-A sensors and reacted for $300 \mathrm{~s}$ with increasing concentrations (black lines; from bottom to top: $50 \mathrm{nM}$; $100 \mathrm{nM}$, and $200 \mathrm{nM}$, as indicated) of either IL-17A (A) or MMP-9 ${ }_{\text {CAT }}$ (B). The sensors were then immersed in a buffer for another $2500 \mathrm{~s}$ (dissociation phase). Red lines indicate curve fitting of a 1:1 binding model and used to determine the $K_{D}$ values. (C) To evaluate the simultaneous binding of the two ligands, a Protein-A sensor coated with $\mathrm{HD}_{\mathrm{N}-\mathrm{TIMP} 2 \mathrm{V3}}$ was submerged in a solution containing IL-17A (leftmost arrow) and the wavelength interference was recorded. Following a short wash (leftmost dashed line), the sensor was immersed in solution containing MMP-9 ${ }_{\text {CAT }}$ (rightmost arrow), followed by another washing step (rightmost dashed line). (D) As a control, a Protein-A sensor coated with V3 was submerged in a solution containing IL-17A and, following a short wash, the sensor was immersed in MMP-9 ${ }_{\mathrm{CAT}}$ followed by another washing step. 


\section{DISCUSSION}

We evaluated the therapeutic potential of targeting the MMP-9/IL-17A axis, which has been ascribed putative pathobiological roles in various types of cancer [32, 36, $37,39]$. To this end, we developed $\mathrm{HD}_{\mathrm{N}-\mathrm{TIMP}, \mathrm{V} 3}$ : a novel bispecific heterodimer that successfully inhibits both MMP9 activation and IL-17A-induced cytokine secretion to synergistically inhibit the invasion of breast cancer cells. Indeed, as the affinity of the N-TIMP2 and V3 domains of the heterodimer to their targets (MMP-9 and IL-17A, respectively) was not compromised, we attribute the improved ability of the heterodimer to inhibit cancer cell invasion to its ability to simultaneously bind both targets.

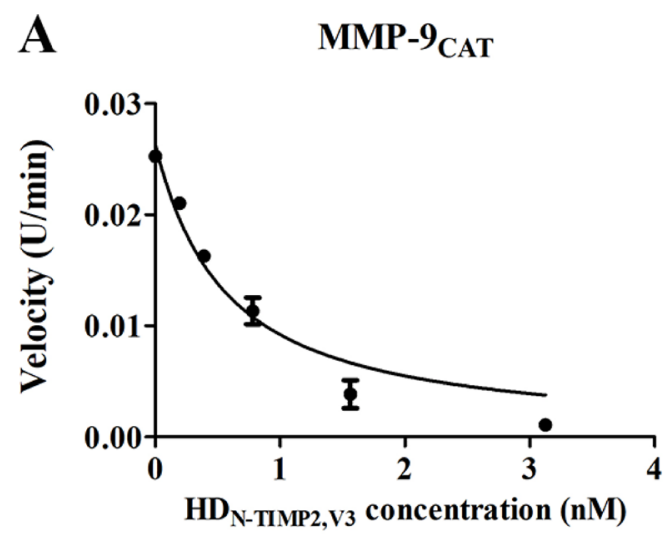

$\mathrm{V} 3$ is a soluble receptor that traps and inhibits IL17A. IL-17A and MMP-9 (a target for N-TIMP) have been shown to cross-interact. It was previously shown that IL$17 \mathrm{~A}$ is associated with an increased expression of MMP9 , leading to enhanced cancer invasiveness and metastasis [13, 29, 32, 36, 39]. In addition, IL-17A-dependent invasion of breast cancer cells can be inhibited by MMP-9 inhibitors [32]. Therefore, it is possible that simultaneous inhibition of both IL-17A and MMP-9 lead to synergism due to the cross-talk between the two pathways.

As such, our findings further highlight the importance of this cross-talk between MMP-9 and IL-17A for cancer cell invasion and migration (as was suggested previously [37]), and they may thus pave the way toward the
B

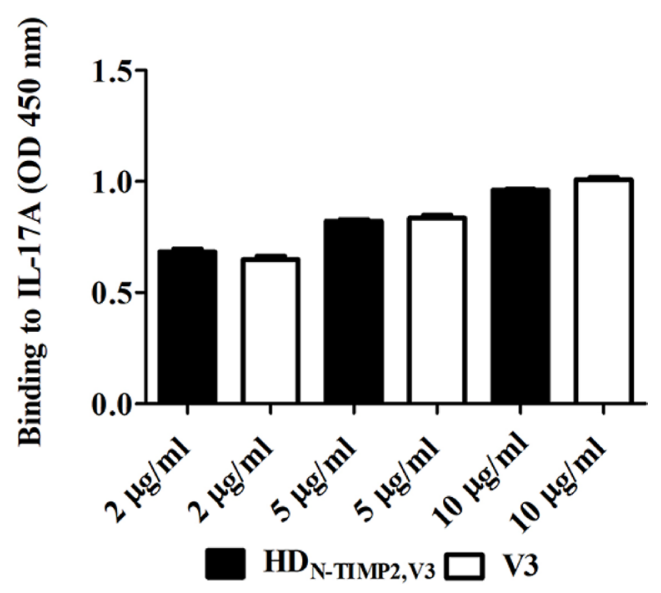

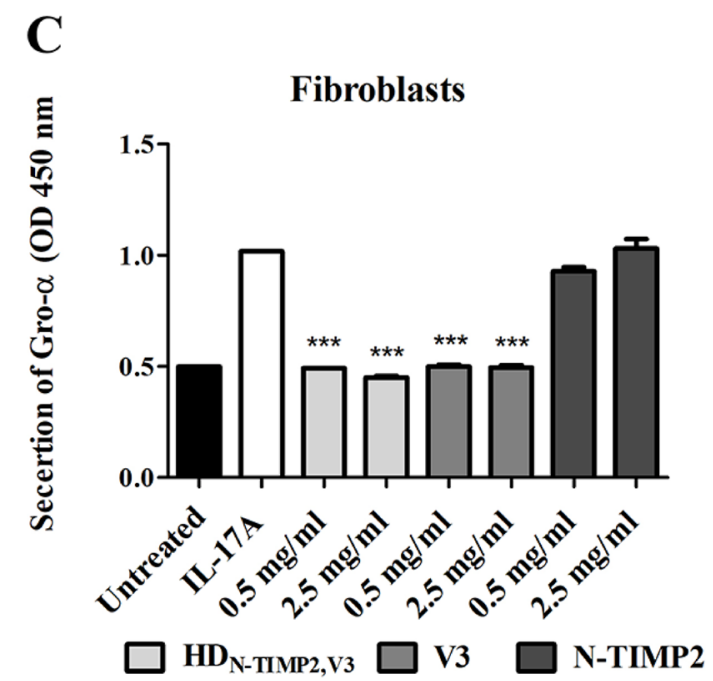

Figure 2: The inhibitory effect of $\mathrm{HD}_{\mathrm{N}-\mathrm{TIMP2}, \mathrm{V} 3}$, versus mono-specific controls, on the activity of MMP-9 ${ }_{\mathrm{CAT}}$ and IL-17A.

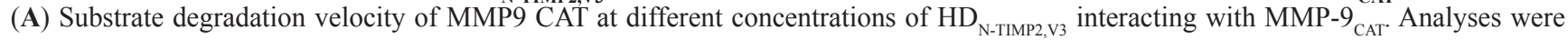
fitted to Morrison's equation (see Eq. 1 in Materials and Methods) to obtain the $K_{i}$ values. (B) An ELISA analysis of the binding of HD TIMP2,V3 and V3, at various concentrations, to immobilized IL-17A. (C) Fibroblast-based assay for the inhibition of IL-17A-induced Gro- $\alpha$ secretion. Cells were incubated with $10 \mathrm{ng} / \mathrm{ml}$ IL-17A and various concentrations of $\mathrm{HD}_{\mathrm{N}-\mathrm{TIMP} 2 \mathrm{~V} 3}$ or of the mono-specific controls (V3 or N-TIMP2). The undiluted cell supernatant was analyzed by ELISA to detect Gro- $\alpha$ levels. Data points indicate the mean ( \pm SEM) of triplicate experiments. ${ }^{* * *} P<0.005$ (Student's $t$-test, compared with cells treated with IL-17A alone). 
development of a new generation of cancer inhibitors, based on the dual targeting of inflammatory and extracellular matrix remodeling pathways. We have previously developed a bi-specific inhibitor that targets both disintegrin and metalloproteinase 17 (ADAM17) and the cytokine TNFlike ligand 1A (TL1A) as a potential therapeutic approach for inflammatory bowel disease [57]. The bi-specific inhibitor exhibited high potency in cell-based assays, as it strongly bound ADAM17, displayed on the cell surface, to improve TL1A inhibition. Thus, a dual targeting of MMPs and pro-inflammatory cytokines can be highly beneficial as a therapeutic strategy for different complex diseases in which extracellular matrix remodeling is associated with an abnormal activation of the immune system.

A somewhat unexpected finding in our study was that the inhibitory effect of $\mathrm{HD}_{\mathrm{N}-\mathrm{TIMP} 2, \mathrm{~V} 3}$ was greater than

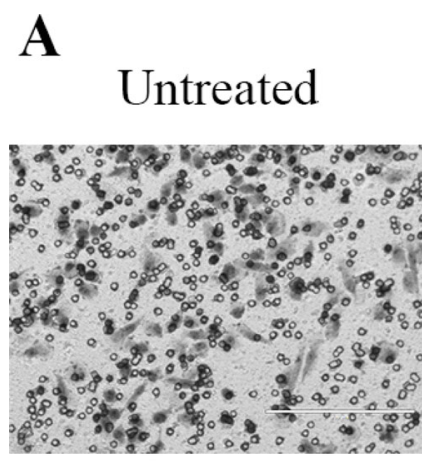

D

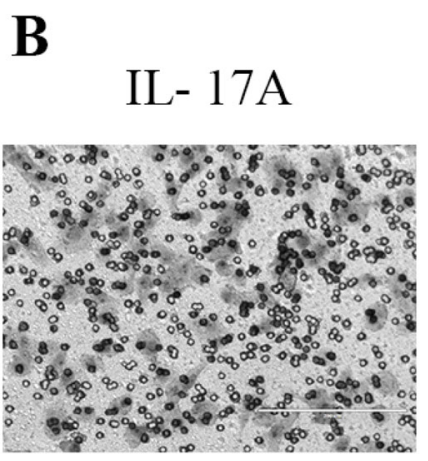

C

$\mathrm{HD}_{\mathrm{N}-\mathrm{TIMP} 2, \mathrm{~V} 3}$

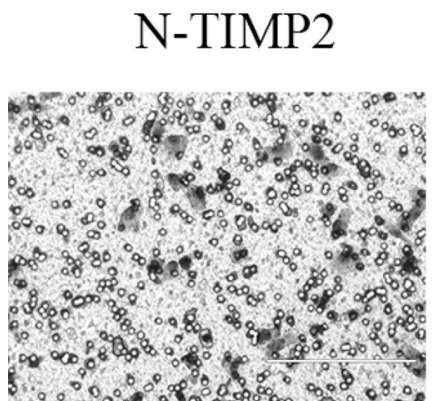

$\mathbf{E}$
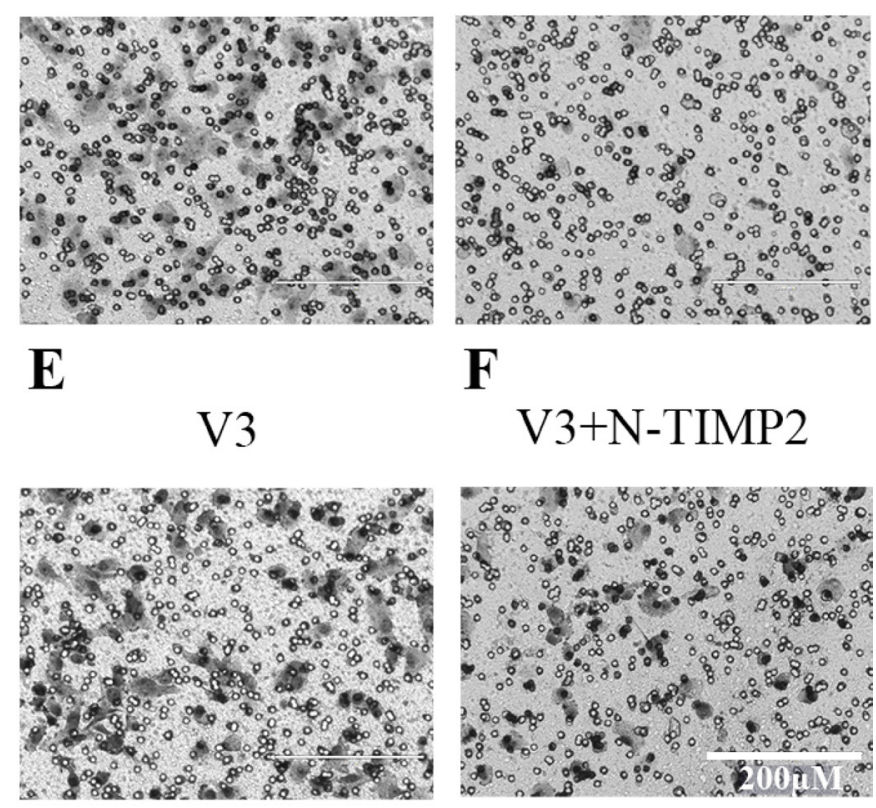

F
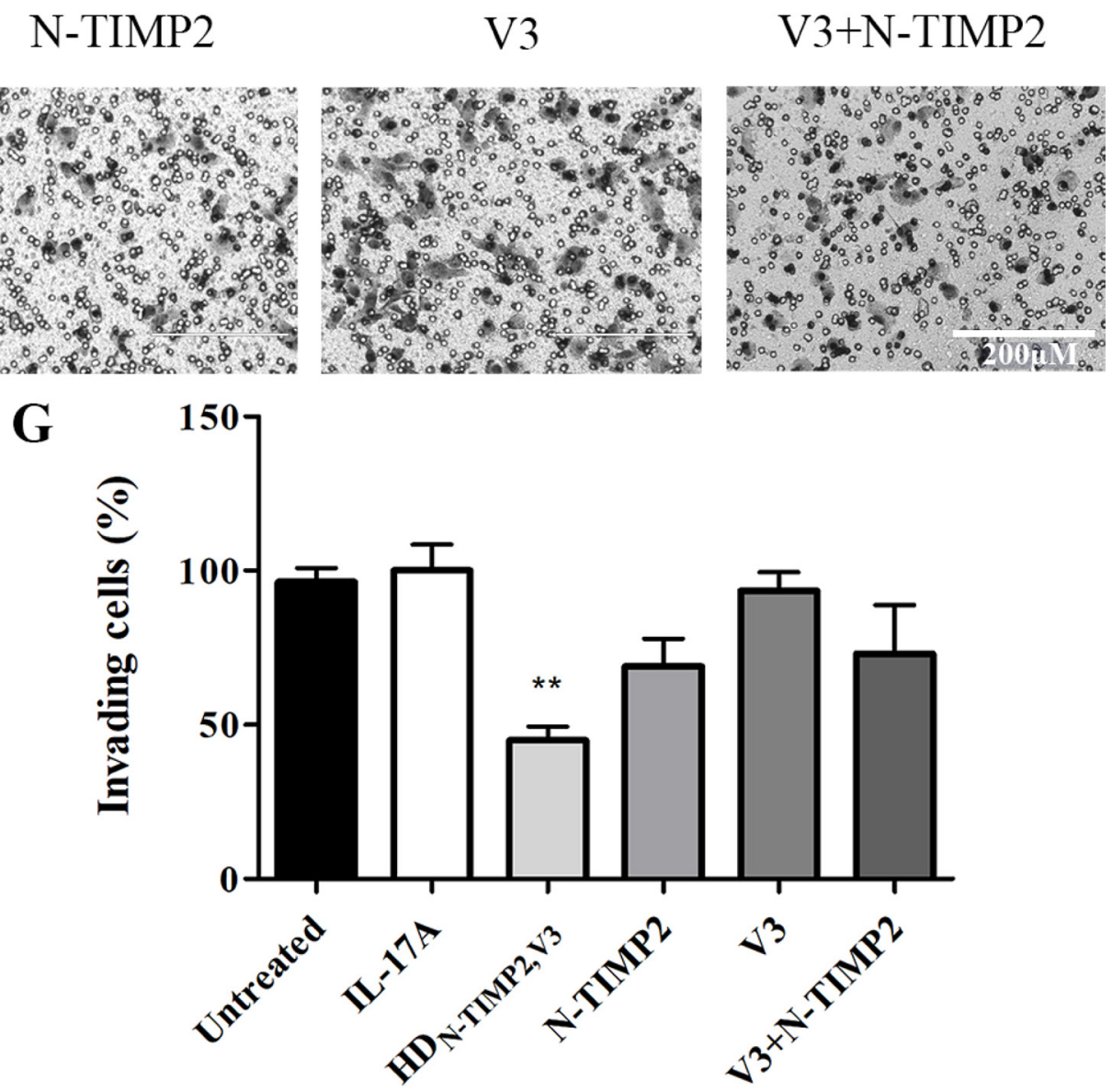

Figure 3: The inhibitory effect of $\mathrm{HD}_{\mathrm{N}-\mathrm{TIMP2}, \mathrm{V} 3}$, versus mono-specific controls, on the invasiveness of MDA-MB-231 cells. MDA-MB-231 cells were treated with IL-17A, either alone or with $\mathrm{HD}_{\mathrm{N}-\mathrm{TIMP} 2 \mathrm{~V} 3}$ or the mono-specific controls, in Boyden chambers. The number of invading cells accumulating on the bottom of the membrane was counted. (A) Untreated cells. (B-F) Cells treated with IL-17A $(10 \mathrm{ng} / \mathrm{ml}, 0.32 \mu \mathrm{M})$, either alone (B) or with $500 \mathrm{nM}$ of $\mathrm{HD}_{\text {N-TIMP2.V3 }}(\mathbf{C})$, N-TIMP2 (D), V3 (E), or N-TIMP2 + V3 (F). Scale bar in $\mathrm{F}$ applies to all images and represents $200 \mu \mathrm{m}$. (G) Quantification of invasive cells, normalized to cells treated with IL-17A alone. Bars represents the mean ( \pm SEM) of triplicate experiments. ${ }^{* *} P<0.01$ (Student's $t$-test, compared with cells treated with IL-17A alone). 
Untreated
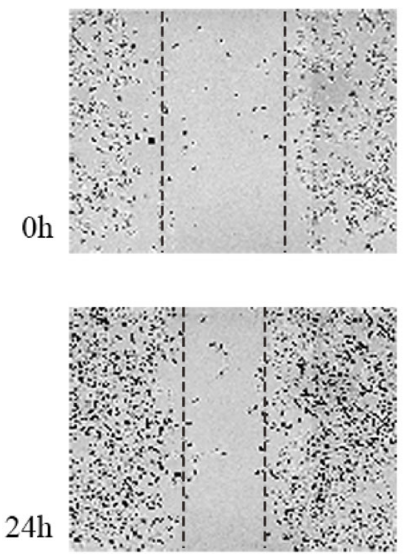

D

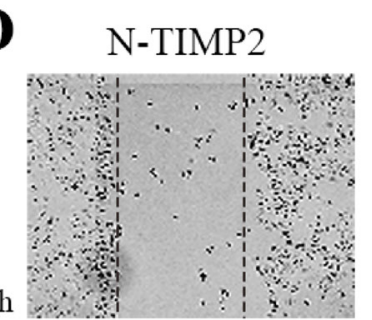

Oh

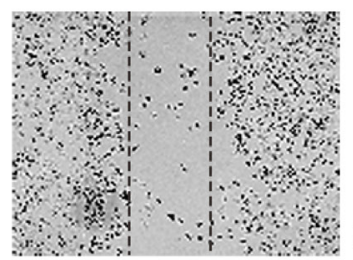

B

oh

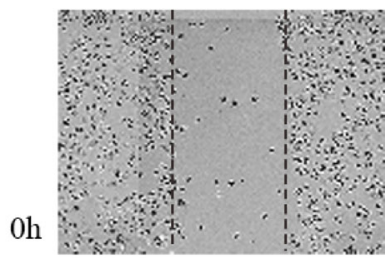

IL- $17 \mathrm{~A}$

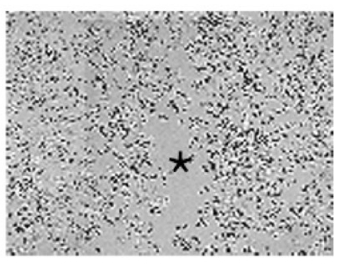

E

oh

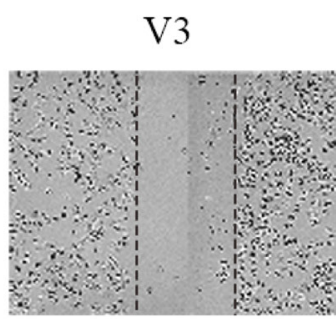

$24 \mathrm{~h}$

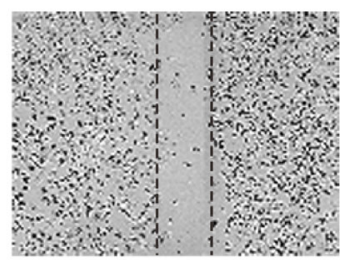

C

HD N-TIMP2,V3

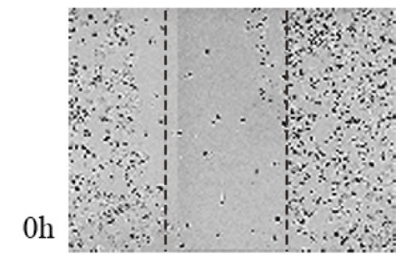

$24 \mathrm{~h}$

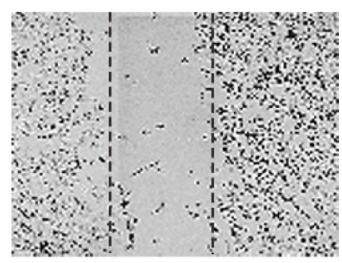

Oh
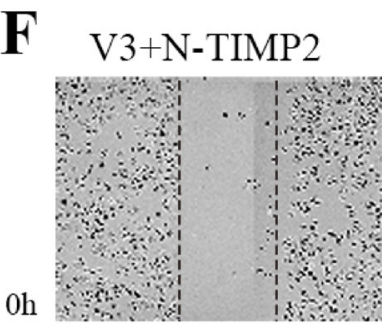

$24 \mathrm{~h}$

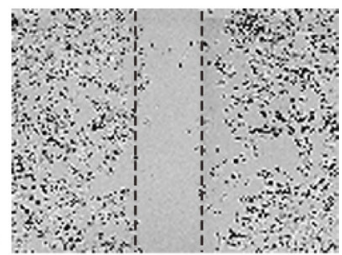

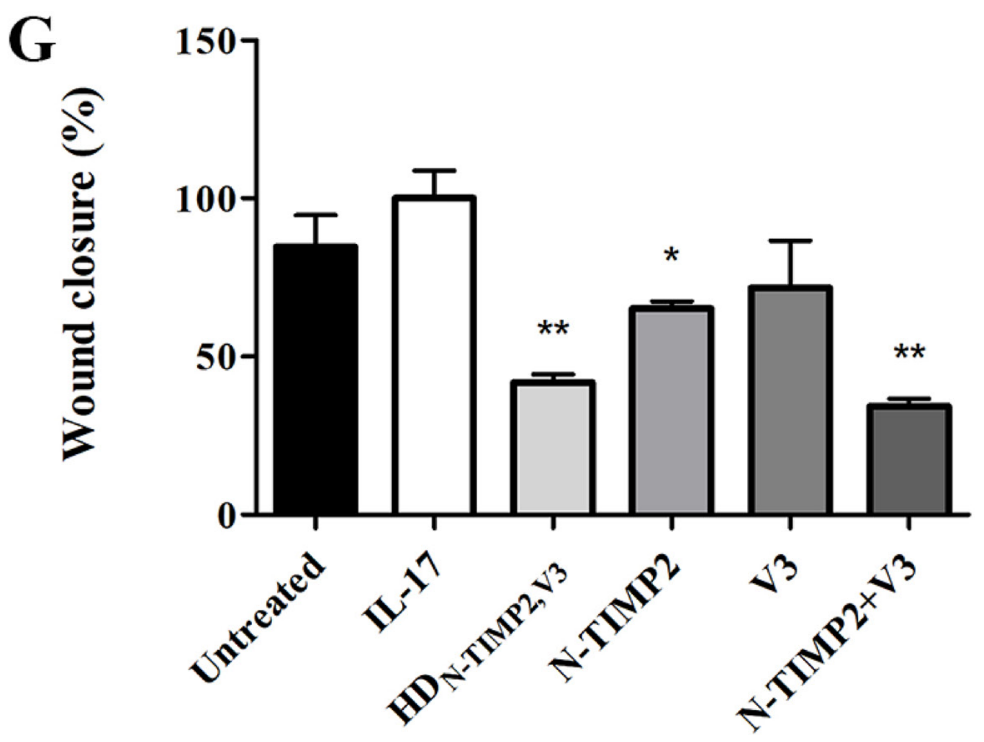

Figure 4: The inhibitory effect of $\mathrm{HD}_{\mathrm{N}-\mathrm{TIMP} 2 \mathrm{~V} 3}$, versus mono-specific controls, on the migration of MDA-MB-231 cells in a scratch assay. MDA-MB-231 cells were scratched by removing a strip across the well. Then, the cells were treated with IL-17A, either alone or with $\mathrm{HD}_{\mathrm{N}-\mathrm{TIMP}, \mathrm{V3}}$ or the mono-specific controls, individually or together, for $24 \mathrm{~h}$. The area free from cells was counted. (A)

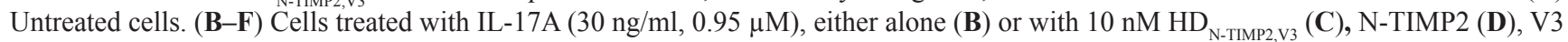
(E), or N-TIMP2 + V3 (F). The asterisk in B represents a full migration of the cells to the scratched area. (G) Quantification of migrating cells, normalized to cells treated with IL-17A alone. Bars represents the mean ( \pm SEM) of triplicate experiments. ${ }^{*} P<0.05,{ }^{* *} P<0.01$ (Student's $t$-test, compared with cells treated with IL-17A alone). 
that of a combination of its two mono-specific counterparts (N-TIMP2 and V3) in the invasion assay, whereas these two treatments had a similar effect in the migration assay. This finding may suggest that the degree of cross-talk between IL-17A and MMP-9 is lower in pathways involved in cancer cell migration than in cancer cell invasion. A hypothesis that will be addressed in future studies.

In addition to inhibiting cancer cell migration and invasion, bi-specific inhibitors that target both MMP-9 and IL-17 can increase the selectivity of treatment to those cancer cells that express both targets, in which the crossreactivity and synergistic action of these targets strongly promote cancer cell invasion $[36,37]$, to improve tumor growth inhibition. Moreover, the improved potency of the bi-specific inhibitor, as compared with its mono-specific counterparts, can potentially reduce the side effects that may arise by inhibiting each target individually, as both MMPs and interleukins naturally play important roles in homeostasis, inflammation, and various important biological functions, such as wound healing [58], cell adhesion [59, 60], and cell differentiation [61].

In summary, our bi-specific inhibitor targeting MMP-9 and IL-17A can pave the way for the generation of additional bi-specific inhibitors targeting metalloproteinases and pro-inflammatory cytokines for targeting tumors in which the cross-talk between extracellular matrix remodeling and the immune system is a major driving force in cancer progression. The next logical step is therefore to directly test the therapeutic efficacy of the engineered bispecific inhibitor, namely, its ability to inhibit tumor growth and reduce multiple metastases in various in vivo primary tumor and experimental metastasis models.

\section{MATERIALS AND METHODS}

\section{Construction of the bi-specific $\mathrm{HD}$ heterodimer}

The pFUSE-hIgG1e3-Fc1 plasmid vector (InvivoGen, San Diego, CA) that contained the bi-specific heterodimer $\mathrm{HD}_{\mathrm{N}-\mathrm{TIMP} 2 \mathrm{~V} 3}$ was designed to include the following components: the N-TIMP2 natural leader peptide (residues 1-26, GenPept: NP_003246, NCBI), followed by N-TIMP2 (residues 1-127 [44]), a flexible linker (SGGGGSGGGGSGGGGS); the soluble extracellular domain of the IL-17A receptor, termed V3 [residues 1-288, including the mutations L10P, R109K, D123G, H156D, G244W, and A268V; [43]]; a human IgG1 Fc, used to increase the serum half-life, and a $6 \times$ His tag sequence at the C-terminus, used for protein purification and detection. The construct was obtained from Integrated DNA Technologies (Coralville, IA), and was amplified using a PCR reaction with a Phusion DNA polymerase (New England Biolabs, Ipswich, MA) with primers that were homologous to the pFUSE plasmid (forward-5'-CTG AGA TCA CCG GTG AAT TCA TGG GTG CAG CCG CAC GC-3'. reverse-
5'-TAT CAT GTC TGG CCA GCT AGC ACT CAG TGA TGG TGA TGG TGA TGG ATA TC-3'). The PCR reaction comprised $10 \mathrm{ng}$ of the construction gene, $1 \mu \mathrm{l}$ of each primer, $0.4 \mu \mathrm{l}$ Phusion DNA polymerase (New England Biolabs), $2 \mu$ DNA polymerase buffer, $2 \mu$ of a dNTP $\operatorname{mix}(10 \mathrm{mM}), 1.2 \mu \mathrm{MgCl}_{2}$, and double deionized water, added to reach a total volume of $20 \mu \mathrm{l}$. The PCR conditions were: $95^{\circ} \mathrm{C}$ for $2 \mathrm{~min}$, followed by 35 cycles at $95^{\circ} \mathrm{C}$ for $20 \mathrm{~s}, 56^{\circ} \mathrm{C}$ for $10 \mathrm{~s}, 70^{\circ} \mathrm{C}$ for $3 \mathrm{~min}$, and a final elongation at $72^{\circ} \mathrm{C}$ for $5 \mathrm{~min}$. The PCR product was cloned into the pFUSE vector by using the Gibson assembly method (New England Biolabs) according to the manufacturer's protocol, followed by transformation into electro-competent $E$. coli cells, which were grown overnight on $25 \mu \mathrm{g} / \mathrm{ml}$ zeocinLB agar plates. Then, 40 colonies were transferred to a $25 \mu \mathrm{g} / \mathrm{ml}$ zeocin-LB culture medium and grown overnight at $37^{\circ} \mathrm{C}$. The plasmid was extracted from the bacteria using the HiYield plasmid mini kit (RBC Bioscience, Taiwan) and was sequenced in the genetics unit of the National Institute for Biotechnology in the Negev (NIBN), Ben-Gurion University of the Negev, Israel.

\section{Production and purification of recombinant proteins}

The production of the bi-specific heterodimer was performed in mammalian HEK293F cells (Invitrogen, Carlsbad, CA), which were maintained in a FreeStyle ${ }^{\mathrm{TM}}$ 293 expression medium (Thermo Fisher Scientific, Waltham, MA). The construct was sub-cloned into the pFUSE mammalian vector, as described above. The HEK293F cells were transiently transformed with $1 \mu \mathrm{g} / \mathrm{ml}$ of DNA according to the FreeStyle 293 System manual, using the GeneTranIII transfection reagent (Biomiga, San Diego, CA). The supernatant was harvested after five days and the medium was then centrifuged for $10 \mathrm{~min}$ at $500 \times \mathrm{g}$ and filtered. The protein was purified from the filtered medium using a metal chelating chromatography with nickel-nitrilotriacetic acid-Sepharose beads (Invitrogen). The beads were washed with $50 \mathrm{mM}$ Tris $(\mathrm{pH} 7.5)$, $100 \mathrm{mM} \mathrm{NaCl}$, and $20 \mathrm{mM}$ imidazole, and, following incubation with the medium, eluted with $50 \mathrm{mM}$ Tris $(\mathrm{pH}$ 7.5), $100 \mathrm{mM} \mathrm{NaCl}$, and $500 \mathrm{mM}$ imidazole. The eluted protein was dialyzed and the buffer was exchanged to $50 \mathrm{mM}$ Tris ( $\mathrm{pH} 7.5$ ), $100 \mathrm{mM} \mathrm{NaCl}$, and $5 \mathrm{mM} \mathrm{CaCl}_{2}$, and was then concentrated with a $10 \mathrm{kDa}$ cutoff Vivaspin (Vivaproducts, Littleton, MA). The protein was analyzed by western blotting, using an anti-human IgG antibody against Fc and an anti- $6 \times$ His antibody against the His tag (both purchased from Abcam, Cambridge, UK), followed by anti-mouse alkaline phosphates (1:5000) (Jackson ImmunoResearch, West Grove, PA) and staining with 5-bromo-4-chloro-3-indolyl phosphate reagent (SigmaAldrich, Saint Louis, MO). N-TIMP2 and V3 were produced as previously described $[43,44]$. The purified proteins were stored at $80^{\circ} \mathrm{C}$ until further analysis. To 
ensure protein purification, an SDS-PAGE analysis was conducted on a $15 \%$ polyacrylamide gel under reducing conditions; the bands were visualized by staining with Instant Blue (CBS Scientific, San Diego, CA) and a mass spectrometry analysis was performed on the purified proteins at the Ilse Katz Institute for Nanoscale Science and Technology, Ben-Gurion University of the Negev, Israel. Protein concentrations were determined by UV-Vis (absorbance at $280 \mathrm{~nm}$ ), using a NanoDrop spectrophotometer (Thermo Fisher Scientific), with an extinction coefficient $\left(\varepsilon_{280}\right)$ of $99,820 \mathrm{M}^{-1} \mathrm{~cm}^{-1}$ for $\mathrm{HD}_{\mathrm{N}-\mathrm{TIMP} 2 \mathrm{~V} 3}, 13,500 \mathrm{M}^{-1} \mathrm{~cm}^{-1}$ for N-TIMP2, and 80,995 $\mathrm{M}^{-1} \mathrm{~cm}^{-1}$ for $\mathrm{V} 3$. The production process yielded an average of approximately $1 \mathrm{mg}$ protein for each variant.

\section{MMP inhibition studies}

The inhibitory activity of the $\mathrm{HD}_{\mathrm{N}-\mathrm{TIMP} 2 \mathrm{~V} 3}$ bi-specific heterodimer and of the N-TIMP2 and V3 mono-specific variants was tested against $0.0075 \mathrm{nM} \mathrm{MMP-9}{ }_{\mathrm{CAT}}$. MMP$9_{\mathrm{CAT}}$ was incubated for $1 \mathrm{~h}$ at $37^{\circ} \mathrm{C}$ with either $0.4-25$

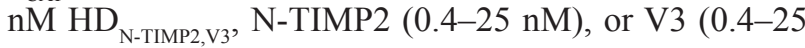
$\mathrm{nM})$ in a TCNB buffer containing $50 \mathrm{mM}$ Tris ( $\mathrm{pH} 7.5)$, $100 \mathrm{mM} \mathrm{NaCl}, 5 \mathrm{mM} \mathrm{CaCl}_{2}$, and $0.05 \%$ Brij. Then, the florigenic substrate Mca-Pro-Leu-Gly-Leu-Dpa-AlaArg-NH2-TFA [where Mca is (7-methoxycoumarin4-yl)acetyl, Dpa is N-3-(2,4-dinitrophenyl)-L-2,3diaminopropionyl, and TFA is trifluoroacetic acid] (Merck Millipore, Darmstadt, Germany) was added to the reaction at a final concentration of $7.5 \mu \mathrm{M}$, and the fluorescence was monitored with 340/30 excitation and 400/30 emission filters, using a Synergy 2 plate reader (BioTek, Winooski, VT) at $37^{\circ} \mathrm{C}$. The reactions were followed spectroscopically for $120 \mathrm{~min}$ and initial rates were determined from the linear portion of the increase in fluorescence signal due to release of the fluorescent MCA group. The tight binding equation, derived from the Morison equation, was used to calculate the dissociation constant $\left(K_{i}\right)$ :

$$
\frac{V_{o}-V_{i}}{V_{i}}=\frac{\left[I_{o}\right]}{K_{i}\left(1+\frac{\left[S_{o}\right]}{K_{m}}\right)}
$$

where $\mathrm{Vi}$ is the steady-state rate in the presence of the inhibitor, $\mathrm{V}_{0}$ is the steady-state rate in the absence of the inhibitor, $\mathrm{K}_{\mathrm{m}}$ is the Michaelis constant for substrate cleavage, and $\left[\mathrm{S}_{0}\right]$ and $\left[\mathrm{I}_{0}\right]$ are the initial concentrations of the substrate and inhibitor, respectively. $K_{i}$ was calculated by plotting the initial velocities against different concentrations of the inhibitors. The inhibition constants reported are the average values obtained from three independent experiments, and the error bars represent the standard error of the mean (SEM). Calculations were performed using $K_{m}$ values of $9.395 \mu \mathrm{M}$ for MMP-9 ${ }_{\mathrm{CAT}}$, as determined from at least three Michaelis-Menten kinetic experiments in our laboratory.

\section{ELISA for IL-17A binding}

ELISA plates (Greiner Bio-One, Kremsmünster, Austria) were incubated with $100 \mu \mathrm{l}$ of $0.5 \mu \mathrm{g} / \mu \mathrm{l}$ goat anti-hIL-17A antibodies (R\&D Systems, Minneapolis, $\mathrm{MN}$ ) for $1 \mathrm{~h}$, washed with PBS supplemented with $0.05 \%$ Tween-80 (PBST), and added with $100 \mu \mathrm{l}$ of $0.35 \mu \mathrm{g} / \mu \mathrm{l}$ IL-17A (PeproTech, Rocky Hill, NJ) for an additional hour. The plates were then washed with PBST and blocked by incubation with $100 \mu$ of PBS supplemented with 3\% skin milk for $1 \mathrm{~h}$. After blocking, the plates were washed, incubated with either $\mathrm{HD}_{\mathrm{N}-\mathrm{TIMP} 2, \mathrm{~V} 3}$, N-TIMP2, or $\mathrm{V} 3$, and shaken for $1 \mathrm{~h}$. The plates were then washed with PBST, incubated for $1 \mathrm{~h}$ with $100 \mu \mathrm{l}$ of $0.05 \mu \mathrm{g} / \mu \mathrm{l}$ goat anti-hIL-17RA antibodies (R\&D Systems), and then incubated with secondary peroxidase-conjugated streptavidin (Jackson ImmunoResearch, 1:10000 dilution). Finally, $100 \mu \mathrm{l}$ of a horseradish peroxidase (HRP) chromogenic 3, 3', 5, 5' tetramethyl benzidine (TMB) substrate solution (Dako, Santa Clara, CA) were added to the plates. The reaction was stopped by adding $1 \mathrm{M}$ sulfuric acid, and it was analyzed using a Tecan Infinite M200 plate reader at $450 \mathrm{~nm}$. Data shown are the average of a triplicate experiment, where error bars represent the SEM. Statistical analyses were performed using Student's $t$-test.

\section{Binding assays using the octet red system}

Binding assays were conducted using bio-layer interferometry by the Octet Red system (ForteBio, Fremont, CA). All steps were performed at $30^{\circ} \mathrm{C}$ with shaking at $1500 \mathrm{rpm}$ in a 96 -well plate $(200 \mu \mathrm{l}$ per well). For $K_{D}$ measurements, the Protein A sensors were loaded with $10 \mu \mathrm{g} / \mathrm{ml}$ of either $\mathrm{HD}_{\mathrm{N}-\mathrm{TIMP} 2, \mathrm{~V} 3}$ or V3 for $300 \mathrm{~s}$ (the loaded protein did not saturate the sensor), followed by washing in PBS supplemented with $1 \%$ BSA and $0.05 \%$ Tween. Then, the sensors were reacted for $300 \mathrm{~s}$ (association phase) with increasing concentrations of the target protein (MMP-9 or IL-17A) and moved to wells that contained the buffer (PBS, $1 \%$ BSA, $0.05 \%$ Tween) for another $1800-2500 \mathrm{~s}$ (dissociation phase). Association and dissociation were measured as changes in light interference over time, and curves are presented after subtracting parallel measurements from unloaded sensors. Sensorgrams were fitted with a 1:1 binding model using the Octet data analysis software (version 8.1), and the $K_{D}$ values were determined. For the simultaneous binding experiments, Protein A sensors were loaded with $10 \mu \mathrm{g} / \mathrm{ml}$ of either $\mathrm{HD}_{\mathrm{N}-\mathrm{TIMP} 2 \mathrm{~V} 3}$ or $\mathrm{V} 3$ for $300 \mathrm{~s}$, and then washed in buffer (PBS, 1\% BSA, 0.05\% Tween). Next, the sensors were reacted with the first target, IL-17A $(10 \mu \mathrm{g} / \mathrm{ml})$, and then with the second target, MMP-9 ${ }_{\text {CAT }}(15 \mu \mathrm{g} / \mathrm{ml})$. The association phase lasted $180 \mathrm{~s}$ and the washing step (dissociation phase) lasted $30 \mathrm{~s}$. 


\section{Cell cultures}

Cells from the MDA-MB-231 human breast cancer cell line (kindly provided by Prof. Smadar Cohen, BenGurion University of the Negev, Israel) were maintained in an RPMI-1640 medium (Biological Industries, Cromwell, CT) supplemented with 10\% FBS (Thermo Fisher Scientific), 1\% L-glutamine (Biological Industries), and $1 \%$ penicillin/streptomycin (Biological Industries). Cells from the CCD-1070Sk normal human skin fibroblast cell line (ATCC) were maintained in an EMEM medium (Biological Industries) supplemented with 10\% FBS, 1\% L-glutamine, and 1\% penicillin/streptomycin.

\section{Inhibition of IL-17A-induced Gro- $\alpha$ secretion in fibroblasts}

The normal human skin fibroblast cell line CCD1070Sk was added to a 96-well plate (Thermo Fisher Scientific), such that each well contained $1 \times 10^{4}$ cells. The plates were incubated for $24 \mathrm{~h}$ at $37^{\circ} \mathrm{C}$ in $5 \% \mathrm{CO}_{2}$ until 95\%-100\% confluency was reached, and they were then stimulated for additional $24 \mathrm{~h}$ with $10 \mathrm{ng} /$ $\mathrm{ml}$ IL-17A (PeproTech) in the presence of $\mathrm{HD}_{\mathrm{N}-\mathrm{TIMP} 2, \mathrm{~V} 3}$ or the mono-specific controls. The cell culture medium was then collected for Gro- $\alpha$ analysis, and Gro- $\alpha$ in culture supernatants was measured using an ELISA kit (PeproTech) according to the manufacturer's guidelines. Data shown is the average of a triplicate experiment, and error bars represent the SEM. Statistical significance was determined using column statistics and Student's $t$-tests, with $p<0.001$ considered statistically significant.

\section{Expression of IL-17A receptor on MDA-MB-231 cell line}

MDA-MB-231 cells were treated with trypsinEDTA (Biological Industries) and divided in 96-well plate, such that each well contained $1 \times 10^{5}$ cells. The cells were centrifuged at $150 \times \mathrm{g}$ for 5 minutes and then washed twice with the buffer assay $(200 \mu$ of $50 \mathrm{mM}$ Tris $\mathrm{HCl} \mathrm{pH}$ 7.5, $5 \mathrm{mM} \mathrm{CaCl}_{2}, 100 \mathrm{mM} \mathrm{NaCl}$ and $\left.0.1 \% \mathrm{BSA}\right)$. Cellular IL-17A receptor levels were detected by adding $100 \mu \mathrm{l}$ biotinylated goat anti- IL-17RA (R\&D Systems, MN, USA) to each well followed by incubation and shaking at $4^{\circ} \mathrm{C}$. The cells were then centrifuged and washed twice with $200 \mu \mathrm{l}$ buffer assay and incubated with $100 \mu \mathrm{l}$ of FITC conjugated neutravidin antibody (Thermo Fisher, MA, USA) for 30 minutes at $4^{\circ} \mathrm{C}$. The cells were then centrifuged and washed twice with $200 \mu$ of buffer assay and were analyzed using Accuri C6 (BD Biosciences, CA, USA) and FlowJo software (Tree star Inc. OR, USA).

\section{Boyden chamber invasion assay}

An in-vitro Boyden chamber assay was performed using ThinCert ${ }^{\mathrm{TM}}$ 24-well inserts (Greiner Bio-One) as previously described, with minor modifications [62]. The ThinCert ${ }^{\mathrm{TM}}$ cell culture insert membranes were coated with Matrigel $^{\circledR}$, diluted 1:30 in an RPMI medium without serum in the upper chamber compartment $(30 \mu \mathrm{g}$ per chamber compartment [63-65]). The lower compartment of the chamber was filled with $600 \mu \mathrm{l}$ RPMI. Then, $3.5 \times 10^{4}$ MDA-MB-231 cells were treated with $10 \mathrm{ng} /$ $\mathrm{ml}$ IL-17A (PeproTech) together with $500 \mathrm{nM}$ of either $\mathrm{HD}_{\text {N-TIMP2,V3 }}$ or the mono-specific variants. The proteins were added to the pre-coated ThinCert ${ }^{\mathrm{TM}}$ cell culture inserts, which were then incubated for $6 \mathrm{~h}$ at $37^{\circ} \mathrm{C}$ under $5 \% \mathrm{CO}_{2}$. Invasive cells were stained with the Dipp Kwik Differential Stain Kit (American MasterTech Scientific, Lodi, CA) and detected using the EVOS FL Cell Imaging System (Thermo Fisher Scientific) at a $\times 20$ magnification. The experiment was performed in a triplicate; in each experiment, 10 fields were counted for each treatment and the average of cells per field was determined. Error bars in figures represent the SEM. Statistical significance was determined by column statistics and Student's $t$-tests, with $p<0.005$ considered significant.

\section{Scratch assay}

MDA-MB-231 cells $\left(9 \times 10^{4}\right.$ cells $)$ were cultured as confluent monolayers in a 24-well plate, and, after they adhered to the plate surface, were scratched by removing a strip across the well with a p200 pipette tip. The scratched monolayers were then washed twice to remove non-adherent cells. Next, $600 \mu \mathrm{l}$ of medium containing $30 \mathrm{ng} / \mathrm{ml} \mathrm{IL-17A} \mathrm{(PeproTech)} \mathrm{and} 10 \mathrm{nM}$ $\mathrm{HD}_{\mathrm{N}-\mathrm{TIMP} 2, \mathrm{~V} 3}$ or the mono-specific variants were added. The plate was photographed at the microscopy unit of the NIBN immediately after performing the scratch, and again $24 \mathrm{~h}$ later, using Operta (PerkinElmer, Waltham, MA) and Harmony 3.1.1 software. The experiment was performed in a triplicate and the images were analyzed using ImageJ. Error bars in the figures represent the SEM, and statistical significance was determined by column statistics and Student's $t$-tests, with $p<0.05$ considered significant.

\section{Abbreviations}

ADAM17: a disintegrin and metalloproteinase 17; IL-17A: interleukin-17A; IL-17RA: interleukin17A receptor; MMP: matrix metalloproteinase; SEM: standard error of the mean; TIMP2: tissue inhibitor of metalloproteinase 2; TL1A: TNF-like ligand 1A.

\section{Author contributions}

D.K., A.A. and N.P. designed the research, D.K and M.S.Z generated the proteins, D.K. performed the research, D.K., A.A. and N.P. analyzed the data, and D.K., A.A. and N.P. wrote the paper. All authors edited the manuscript and approved the final version. 


\section{ACKNOWLEDGMENTS AND FUNDING}

The authors thank Dr. Alon Zilka for his technical assistance. Octet experiments were performed at the IIBR antibody engineering unit. This work was supported by the European Research Council "Ideas program" ERC-2013-StG (contract grant number: 336041) to Niv Papo, the Israeli Science foundation (ISF) grant number 2297/15 and the European research training network (ITN, Horizon 2020) ES-cat (722610) for Amir Aharoni.

\section{CONFLICTS OF INTEREST}

The authors declare that they have no conflicts of interest with respect to publication of this paper.

\section{REFERENCES}

1. Weiner GJ. Building better monoclonal antibody-based therapeutics. Nat Rev Cancer. 2015; 15:361-70. https:// doi.org/10.1038/nrc3930.

2. Kontermann RE. Dual targeting strategies with bispecific antibodies. MAbs. 2012; 4:182-97. https:// doi.org/10.4161/mabs.4.2.19000.

3. Papo N, Silverman AP, Lahti JL, Cochran JR. Antagonistic VEGF variants engineered to simultaneously bind to and inhibit VEGFR2 and alphavbeta3 integrin. Proc Natl Acad Sci U S A. 2011; 108:14067-72. https:// doi.org/10.1073/pnas.1016635108.

4. Garber K. Bispecific antibodies rise again. Nat Rev Drug Discov. 2014; 13:799-801. https://doi.org/10.1038/nrd4478.

5. Kloepper J, Riedemann L, Amoozgar Z, Seano G, Susek $\mathrm{K}$, Yu V, Dalvie N, Amelung RL, Datta M, Song JW, Askoxylakis V, Taylor JW, Lu-Emerson C, et al. Ang-2/ VEGF bispecific antibody reprograms macrophages and resident microglia to anti-tumor phenotype and prolongs glioblastoma survival. Proc Natl Acad Sci U S A. 2016; 113:4476-81. https://doi.org/10.1073/pnas.1525360113.

6. Li C, Huang S, Armstrong EA, Francis DM, Werner LR, Sliwkowski MX, van der Kogel A, Harari PM. Antitumor Effects of MEHD7945A, a Dual-Specific Antibody against EGFR and HER3, in Combination with Radiation in Lung and Head and Neck Cancers. Mol Cancer Ther. 2015; 14:2049-59. https://doi.org/10.1158/1535-7163.MCT-15-0155.

7. Schaefer G, Haber L, Crocker LM, Shia S, Shao L, Dowbenko D, Totpal K, Wong A, Lee CV, Stawicki S, Clark R, Fields C, Lewis Phillips GD, et al. A two-in-one antibody against HER3 and EGFR has superior inhibitory activity compared with monospecific antibodies. Cancer Cell. 2011; 20:472-86. https://doi.org/10.1016/j.ccr.2011.09.003.

8. Xiong D, Xu Y, Liu H, Peng H, Shao X, Lai Z, Fan D, Yang M, Han J, Xie Y, Yang C, Zhu Z. Efficient inhibition of human B-cell lymphoma xenografts with an anti-CD20 x anti-CD3 bispecific diabody. Cancer Lett. 2002; 177:29-39. https://doi.org/10.1016/S0304-3835(01)00758-3.

9. Brinkmann U, Kontermann RE. The making of bispecific antibodies. MAbs. 2017; 9:182-212. https://doi.org/10.108 0/19420862.2016.1268307.

10. Chen S, Li J, Li Q, Wang Z. Bispecific antibodies in cancer immunotherapy. Hum Vaccin Immunother. 2016; 12:2491500. https://doi.org/10.1080/21645515.2016.1187802.

11. Chung $\mathrm{CH}$. Managing premedications and the risk for reactions to infusional monoclonal antibody therapy. Oncologist. 2008; 13:725-32. https:// doi.org/10.1634/theoncologist.2008-0012.

12. Wasilewska A, Winiarska M, Olszewska M, Rudnicka L. Interleukin-17 inhibitors. A new era in treatment of psoriasis and other skin diseases. Postepy Dermatol Alergol. 2016; 33:247-52. https://doi.org/10.5114/ada.2016.61599.

13. Zou W, Restifo NP. T(H)17 cells in tumour immunity and immunotherapy. Nat Rev Immunol. 2010; 10:248-56. https://doi.org/10.1038/nri2742. Erratum in: Nat Rev Immunol. 2011; 11:565.

14. Kobayashi T, Kim H, Liu X, Sugiura H, Kohyama T, Fang Q, Wen FQ, Abe S, Wang X, Atkinson JJ, Shipley JM, Senior RM, Rennard SI. Matrix metalloproteinase-9 activates TGF- $\beta$ and stimulates fibroblast contraction of collagen gels. Am J Physiol Lung Cell Mol Physiol. 2014; 306:L1006-15. https://doi.org/10.1152/ajplung.00015.2014.

15. Itoh T, Tanioka M, Matsuda H, Nishimoto H, Yoshioka T, Suzuki R, Uehira M. Experimental metastasis is suppressed in MMP-9-deficient mice. Clin Exp Metastasis. 1999; 17:177-81. https://doi.org/10.1023/A:1006603723759.

16. Benson CS, Babu SD, Radhakrishna S, Selvamurugan N, Ravi Sankar B. Expression of matrix metalloproteinases in human breast cancer tissues. Dis Markers. 2013; 34:395405. https://doi.org/10.1155/2013/420914.

17. Kachra Z, Beaulieu E, Delbecchi L, Mousseau N, Berthelet F, Moumdjian R, Del Maestro R, Béliveau R. Expression of matrix metalloproteinases and their inhibitors in human brain tumors. Clin Exp Metastasis. 1999; 17:555-66. https://doi.org/10.1023/A:1006760632766.

18. Lin LF, Chuang CH, Li CF, Liao CC, Cheng CP, Cheng TL, Shen MR, Tseng JT, Chang WC, Lee WH, Wang JM. ZBRK1 acts as a metastatic suppressor by directly regulating MMP9 in cervical cancer. Cancer Res. 2010; 70:192-201. https:// doi.org/10.1158/0008-5472.CAN-09-2641.

19. Rao JS, Gondi C, Chetty C, Chittivelu S, Joseph PA, Lakka SS. Inhibition of invasion, angiogenesis, tumor growth, and metastasis by adenovirus-mediated transfer of antisense UPAR and MMP-9 in non-small cell lung cancer cells. Mol Cancer Ther. 2005; 4:1399-408. https:// doi.org/10.1158/1535-7163.MCT-05-0082. 
20. Redondo P, Lloret P, Idoate M, Inoges S. Expression and serum levels of MMP-2 and MMP-9 during human melanoma progression. Clin Exp Dermatol. 2005; 30:54145. https://doi.org/10.1111/j.1365-2230.2005.01849.x.

21. Roomi MW, Kalinovsky T, Rath M, Niedzwiecki A. Effect of a nutrient mixture on matrix metalloproteinase- 9 dimers in various human cancer cell lines. Int J Oncol. 2014; 44:986-92. https://doi.org/10.3892/ijo.2013.2235.

22. Zucker S, Lysik RM, Zarrabi MH, Moll U. M(r) 92,000 type IV collagenase is increased in plasma of patients with colon cancer and breast cancer. Cancer Res. 1993; 53:140-46.

23. Daroqui MC, Vazquez P, Bal de Kier Joffé E, Bakin AV, Puricelli LI. TGF- $\beta$ autocrine pathway and MAPK signaling promote cell invasiveness and in vivo mammary adenocarcinoma tumor progression. Oncol Rep. 2012; 28:567-75. https://doi.org/10.3892/or.2012.1813.

24. Wu QW, Yang QM, Huang YF, She HQ, Liang J, Yang QL, Zhang ZM. Expression and clinical significance of matrix metalloproteinase-9 in lymphatic invasiveness and metastasis of breast cancer. PLoS One. 2014; 9:e97804. https://doi.org/10.1371/journal.pone.0097804.

25. Aggarwal S, Ghilardi N, Xie MH, de Sauvage FJ, Gurney AL. Interleukin-23 promotes a distinct CD4 $\mathrm{T}$ cell activation state characterized by the production of interleukin-17. J Biol Chem. 2003; 278:1910-14. https:// doi.org/10.1074/jbc.M207577200.

26. Onishi RM, Gaffen SL. Interleukin-17 and its target genes: mechanisms of interleukin-17 function in disease. Immunology. 2010; 129:311-21. https:// doi.org/10.1111/j.1365-2567.2009.03240.x.

27. Chang SH, Mirabolfathinejad SG, Katta H, Cumpian AM, Gong L, Caetano MS, Moghaddam SJ, Dong C. T helper 17 cells play a critical pathogenic role in lung cancer. Proc Natl Acad Sci U S A. 2014; 111:5664-69. https:// doi.org/10.1073/pnas.1319051111.

28. Coffelt SB, Kersten K, Doornebal CW, Weiden J, Vrijland K, Hau CS, Verstegen NJ, Ciampricotti M, Hawinkels LJ, Jonkers J, de Visser KE. IL-17-producing $\gamma \delta \mathrm{T}$ cells and neutrophils conspire to promote breast cancer metastasis. Nature. 2015; 522:345-48. https:// doi.org/10.1038/nature14282.

29. Ernst M, Putoczki T. IL-17 cuts to the chase in colon cancer. Immunity. 2014; 41:880-82. https:// doi.org/10.1016/j.immuni.2014.12.004.

30. Grivennikov SI, Wang K, Mucida D, Stewart CA, Schnabl B, Jauch D, Taniguchi K, Yu GY, Osterreicher CH, Hung KE, Datz C, Feng Y, Fearon ER, et al. Adenoma-linked barrier defects and microbial products drive IL-23/IL-17mediated tumour growth. Nature. 2012; 491:254-58. https://doi.org/10.1038/nature11465.

31. Xu B, Guenther JF, Pociask DA, Wang Y, Kolls JK, You Z, Chandrasekar B, Shan B, Sullivan DE, Morris GF. Promotion of lung tumor growth by interleukin-17. Am
J Physiol Lung Cell Mol Physiol. 2014; 307:L497-508. https://doi.org/10.1152/ajplung.00125.2014.

32. Zhu X, Mulcahy LA, Mohammed RA, Lee AH, Franks HA, Kilpatrick L, Yilmazer A, Paish EC, Ellis IO, Patel PM, Jackson AM. IL-17 expression by breast-cancer-associated macrophages: IL-17 promotes invasiveness of breast cancer cell lines. Breast Cancer Res. 2008; 10:R95. https:// doi.org/10.1186/bcr2195.

33. Wang L, Yi T, Kortylewski M, Pardoll DM, Zeng D, Yu H. IL-17 can promote tumor growth through an IL-6-Stat3 signaling pathway. J Exp Med. 2009; 206:1457-64. https:// doi.org/10.1084/jem.20090207.

34. Yang B, Kang H, Fung A, Zhao H, Wang T, Ma D. The role of interleukin 17 in tumour proliferation, angiogenesis, and metastasis. Mediators Inflamm. 2014; 2014:623759. https:// doi.org/10.1155/2014/623759.

35. Hayata K, Iwahashi M, Ojima T, Katsuda M, Iida T, Nakamori M, Ueda K, Nakamura M, Miyazawa M, Tsuji T, Yamaue H. Inhibition of IL-17A in tumor microenvironment augments cytotoxicity of tumor-infiltrating lymphocytes in tumor-bearing mice. PLoS One. 2013; 8:e53131. https:// doi.org/10.1371/journal.pone.0053131.

36. Wang Y, Wu H, Wu X, Bian Z, Gao Q. Interleukin 17A promotes gastric cancer invasiveness via NF- $\mathrm{B}$ mediated matrix metalloproteinases 2 and 9 expression. PLoS One. 2014; 9:e96678. https://doi.org/10.1371/journal.pone.0096678.

37. Li J, Lau GK, Chen L, Dong SS, Lan HY, Huang XR, Li Y, Luk JM, Yuan YF, Guan XY. Interleukin $17 \mathrm{~A}$ promotes hepatocellular carcinoma metastasis via NF-kB induced matrix metalloproteinases 2 and 9 expression. PLoS One. 2011; 6:e21816. https:// doi.org/10.1371/journal.pone.0021816.

38. Cheng G, Wei L, Xiurong W, Xiangzhen L, Shiguang Z, Songbin F. IL-17 stimulates migration of carotid artery vascular smooth muscle cells in an MMP-9 dependent manner via p38 MAPK and ERK1/2-dependent NF-kappaB and AP-1 activation. Cell Mol Neurobiol. 2009; 29:1161-8. https://doi.org/10.1007/s10571-009-9409-z.

39. Feng M, Wang Y, Chen K, Bian Z, Wu J, Gao Q. IL-17A promotes the migration and invasiveness of cervical cancer cells by coordinately activating MMPs expression via the p38/NF-кB signal pathway. PLoS One. 2014; 9:e108502. https://doi.org/10.1371/journal.pone.0108502.

40. Lotti F, Jarrar AM, Pai RK, Hitomi M, Lathia J, Mace A, Gantt GA Jr, Sukhdeo K, DeVecchio J, Vasanji A, Leahy P, Hjelmeland AB, Kalady MF, Rich JN. Chemotherapy activates cancer-associated fibroblasts to maintain colorectal cancer-initiating cells by IL-17A. J Exp Med. 2013; 210:2851-72. https://doi.org/10.1084/jem.20131195.

41. Wang K. Targeting IL-17 for cancer-associated inflammation and immunity. The Journal of Immunology. 2017 (Suppl 1); 198:66.5.

42. Liu F, Zhang T, Zou S, Jiang B, Hua D. B7-H3 promotes cell migration and invasion through the Jak2/Stat3/MMP9 
signaling pathway in colorectal cancer. Mol Med Rep. 2015; 12:5455-60. https://doi.org/10.3892/mmr.2015.4050.

43. Zaretsky M, Etzyoni R, Kaye J, Sklair-Tavron L, Aharoni A. Directed evolution of a soluble human IL-17A receptor for the inhibition of psoriasis plaque formation in a mouse model. Chem Biol. 2013; 20:202-11. https:// doi.org/10.1016/j.chembiol.2012.11.012.

44. Arkadash V, Yosef G, Shirian J, Cohen I, Horev Y, Grossman M, Sagi I, Radisky ES, Shifman JM, Papo N. Development of High Affinity and High Specificity Inhibitors of Matrix Metalloproteinase 14 through Computational Design and Directed Evolution. J Biol Chem. 2017; 292:3481-95. https://doi.org/10.1074/jbc.M116.756718.

45. Murphy G, Houbrechts A, Cockett MI, Williamson RA, O'Shea M, Docherty AJ. The N-terminal domain of tissue inhibitor of metalloproteinases retains metalloproteinase inhibitory activity. Biochemistry. 1991; 30:8097-102. https://doi.org/10.1021/bi00247a001.

46. Butler GS, Hutton M, Wattam BA, Williamson RA, Knäuper V, Willenbrock F, Murphy G. The specificity of TIMP-2 for matrix metalloproteinases can be modified by single amino acid mutations. J Biol Chem. 1999; 274:20391-96. https:// doi.org/10.1074/jbc.274.29.20391.

47. Tootle TL, Rebay I. Post-translational modifications influence transcription factor activity: a view from the ETS superfamily. BioEssays. 2005; 27:285-98. https:// doi.org/10.1002/bies.20198.

48. Sharabi O, Shirian J, Grossman M, Lebendiker M, Sagi I, Shifman J. Affinity- and specificity-enhancing mutations are frequent in multispecific interactions between TIMP2 and MMPs. PLoS One. 2014; 9:e93712. https:// doi.org/10.1371/journal.pone.0093712.

49. Shirian J, Sharabi O, Shifman JM. Cold Spots in Protein Binding. Trends Biochem Sci. 2016; 41:739-45. https:// doi.org/10.1016/j.tibs.2016.07.002.

50. Abdiche Y, Malashock D, Pinkerton A, Pons J. Determining kinetics and affinities of protein interactions using a parallel real-time label-free biosensor, the Octet. Anal Biochem. 2008; 377:209-17. https://doi.org/10.1016/j.ab.2008.03.035.

51. Witowski J, Pawlaczyk K, Breborowicz A, Scheuren A, Kuzlan-Pawlaczyk M, Wisniewska J, Polubinska A, Friess H, Gahl GM, Frei U, Jörres A. IL-17 stimulates intraperitoneal neutrophil infiltration through the release of GRO $\alpha$ chemokine from mesothelial cells. J Immunol. 2000; 165:5814-21. https://doi.org/10.4049/jimmunol.165.10.5814.

52. Devy L, Huang L, Naa L, Yanamandra N, Pieters H, Frans N, Chang E, Tao Q, Vanhove M, Lejeune A, van Gool R, Sexton DJ, Kuang G, et al. Selective inhibition of matrix metalloproteinase-14 blocks tumor growth, invasion, and angiogenesis. Cancer Res. 2009; 69:1517-26. https:// doi.org/10.1158/0008-5472.CAN-08-3255.

53. Yan T, Lin Z, Jiang J, Lu S, Chen M, Que H, He X, Que G, Mao J, Xiao J, Zheng Q. MMP14 regulates cell migration and invasion through epithelial-mesenchymal transition in nasopharyngeal carcinoma. Am J Transl Res. 2015; 7:950-58.

54. Yu Q, Stamenkovic I. Cell surface-localized matrix metalloproteinase-9 proteolytically activates TGF-beta and promotes tumor invasion and angiogenesis. Genes Dev. 2000; 14:163-76.

55. Jiang WG, Davies G, Martin TA, Parr C, Watkins G, Mason MD, Mansel RE. Expression of membrane type-1 matrix metalloproteinase, MT1-MMP in human breast cancer and its impact on invasiveness of breast cancer cells. Int J Mol Med. 2006; 17:583-90.

56. Welte $\mathrm{T}$, Zhang XH. Interleukin-17 Could Promote Breast Cancer Progression at Several Stages of the Disease. Mediators Inflamm. 2015; 2015:804347. https:// doi.org/10.1155/2015/804347.

57. Weizman T, Levin I, Zaretsky M, Sagi I, Aharoni A. Increased Potency of a Bi-specific TL1A-ADAM17 (TACE) Inhibitor by Cell Surface Targeting. Front Mol Biosci. 2017; 4:61. https://doi.org/10.3389/fmolb.2017.00061.

58. Caley MP, Martins VL, O'Toole EA. Metalloproteinases and Wound Healing. Adv Wound Care (New Rochelle). 2015; 4:225-34. https://doi.org/10.1089/wound.2014.0581.

59. Zhang H, Chen J, Liu X, Awar L, McMickle A, Bai F, Nagarajan S, Yu S. IL-17 induces expression of vascular cell adhesion molecule through signalling pathway of NF-kB, but not Akt1 and TAK1 in vascular smooth muscle cells. Scand J Immunol. 2013; 77:230-37. https:// doi.org/10.1111/sji.12030.

60. Sternlicht MD, Werb Z. How matrix metalloproteinases regulate cell behavior. Annu Rev Cell Dev Biol. 2001; 17:463516. https://doi.org/10.1146/annurev.cellbio.17.1.463.

61. Srenathan U, Steel K, Taams LS. IL-17+ CD8+ T cells: Differentiation, phenotype and role in inflammatory disease. Immunol Lett. 2016; 178:20-26. https:// doi.org/10.1016/j.imlet.2016.05.001.

62. Tamura M, Gu J, Takino T, Yamada KM. Tumor suppressor PTEN inhibition of cell invasion, migration, and growth: differential involvement of focal adhesion kinase and p130Cas. Cancer Res. 1999; 59:442-49.

63. Fukushima T, Kawaguchi M, Yamasaki M, Tanaka H, Yorita $\mathrm{K}$, Kataoka H. Hepatocyte growth factor activator inhibitor type 1 suppresses metastatic pulmonary colonization of pancreatic carcinoma cells. Cancer Sci. 2011; 102:407-13. https://doi.org/10.1111/j.1349-7006.2010.01808.x.

64. Vallabhaneni KC, Penfornis P, Xing F, Hassler Y, Adams KV, Mo YY, Watabe K, Pochampally R. Stromal cell extracellular vesicular cargo mediated regulation of breast cancer cell metastasis via ubiquitin conjugating enzyme E2 N pathway. Oncotarget. 2017; 8:109861-76. https:// doi.org/10.18632/oncotarget.22371. 
65. Zhang Y, Nolan M, Yamada H, Watanabe M, Nasu Y, Takei K, Takeda T. Dynamin2 GTPase contributes to invadopodia formation in invasive bladder cancer cells. Biochem
Biophys Res Commun. 2016; 480:409-14. https:// doi.org/10.1016/j.bbrc.2016.10.063. 